University of Nebraska - Lincoln DigitalCommons@University of Nebraska - Lincoln

2006

\title{
Temporal Scales and Archaeological Landscapes from the Eastern Desert of Australia and Intermontane North America
}

\author{
Simon J. Holdaway \\ Auckland University, sj.holdaway@auckland.ac.nz \\ LuAnn Wandsnider \\ University of Nebraska-Lincoln, lwandsnider1@unl.edu
}

Follow this and additional works at: http://digitalcommons.unl.edu/anthropologyfacpub

Part of the Archaeological Anthropology Commons

Holdaway, Simon J. and Wandsnider, LuAnn, "Temporal Scales and Archaeological Landscapes from the Eastern Desert of Australia and Intermontane North America" (2006). Anthropology Faculty Publications. 80.

http://digitalcommons.unl.edu/anthropologyfacpub/80

This Article is brought to you for free and open access by the Anthropology, Department of at DigitalCommons@University of Nebraska - Lincoln. It has been accepted for inclusion in Anthropology Faculty Publications by an authorized administrator of DigitalCommons@University of Nebraska Lincoln. 


\section{CONFRONTING SCALE IN ARCHAEOLOGY Issues of Theory and Practice}

Edited by

Gary Lock

University of Oxford

Oxford, United Kingdom

and

Brian Leigh Molyneaux

University of South Dakota

Vermillion, South Dakota, USA

Published by Springer 2006 . 


\title{
Temporal Scales and Archaeological Landscapes from the Eastern Desert of Australia and Intermontane North America
}

\author{
SIMON J. HOLDAWAY AND \\ LUANN WANDSNIDER
}

\section{INTRODUCTION}

Time gets much less attention than space in discussions of archaeological scale. This may seem strange in a primarily historical discipline for which the demonstration of human antiquity is something of a defining moment (Grayson, 1983). Part of the reason may lie in the nature of time. Time unfolds along a continuum, and the way observers perceive time depends on their location and the scales they adopt. Compare the contemporary Western experience of earth time, for example, with time at the scale of the universe. A person traveling at the speed of light would experience a different time (Hawking, 1998; Ramenofsky, 1998) than the person caught up in the linear progression of our planet-bound life. Of course, archaeologists rarely deal with quantum time, but the example serves to remind us that time is not an absolute dimension. Archaeologists create their own conceptual units for measuring time. They project these units at different scales and choose their own observation points, dividing the continuum of time into arbitrary packages that relate in some way to specific research goals (Ramenofsky, 1998).

Few archaeologists have grappled explicitly with scale issues. Crumley (1979) and Marquardt (1992; see also Crumley and Marquardt, 1987) emphasize that social and economic processes may each resolve best at different spatial scales. Stein 
(1993) attempts to reconcile the vastly different temporal scales of geology and archaeology. Most recently, Dobres (2000; see also Lock and Molyneaux, this volume) differentiates between the phenomenological scales at which events contributing to archaeological deposits unfold (i.e., activities, behaviors, and practices) and the interpretative scales of archaeological reasoning (i.e., generalized, theoretically informed). The former are comprehensible in what Binford (1981) refers to as "ethnographic time" and what Stein (1993) calls "human time"; the latter are timeless or time-free.

Dobres contrasts phenomenological and interpretative scales with the analytic scales that researchers use. The choice depends on their research interests (see also Crumley, 1979; Marquardt, 1992) and on the nature of archaeological deposits. As her focus is primarily on agency at individual and collective levels, she emphasizes the phenomenological scale, but she insists that phenomenological, interpretative, and analytical scales have no necessary relationship. Thus, when pursuing such interpretative goals as agency, archaeologists are not limited to one particular scale of phenomena. Nor, according to a close reading of Dobres, are they limited by the nature of the archaeological record, as the scale at which they view the material record is not related to any particular phenomenological scale of agency.

In this chapter, we explicitly focus on archaeological temporal scale, by which we mean both the temporal structure of the phenomenon we study, i.e., the archaeological deposit, and the scales of measurement and interpretation we bring to that phenomenon. Temporal structure refers to (1) the grain, resolution, or microstratigraphic acuity and (2) the extent or scope of phenomena represented in archaeological deposits, observations and interpretations. Grain (Binford, 1980; O'Neill and King, 1998:7), resolution (Behrensmeyer, et al., 2000; Ramenofsky and Steffen, 1998:4-5; Stein, 1993:2) and microstratigraphic acuity (Schindel, 1982) refer to the smallest resolvable temporal interval in an observation set. Extent (O'Neill and King, 1998:7) and scope (Schindel, 1982) refer to the total expanse of time represented in an observation set (see also inclusiveness - Ramenofsky and Steffen, 1998:4-5). To these, Schindel (1982) adds (3) temporal sequence completeness, as many deposits are records of depositional gaps as well as accumulations.

Ecologists O'Neill and King (1998:7) offer important observations on how scale of observation and measurement affect the effective grain and extent of deposits. They note, for instance, that the sampling frequency in time influences the grain of observation, a relationship described elsewhere as the $N y q u i s t$ principle. Similarly, the time span of a particular measurement necessarily influences grain. The practice of calculating means for some span of time necessarily coarsens the grain while subsampling a sequence reduces its extent. In archaeology, both behavior and geological processes contribute to grain (resolution), extent (scope), and completeness of sequences. Measurement practices further affect these aspects of temporal scale.

While Dobres argues that there is no necessary relationship between phenomenological, interpretative, and analytical scales, we follow geoarchaeologists, geomorphologists, paleontologists, and ecologists in emphasizing that the nature of archaeological deposits very much determines the analytical scale - and therefore 
the range of interpretative scales (see Murray, 2003; Stein, 1993:5; Stern, 1993, 1994; Stern, et al., 2002). Thus while the archaeological record may potentially be viewed at a variety of different scales from a range of different view points, issues of compatibility between data, analysis and interpretation cannot be ignored. We begin with this point, using it as the basis for a critique of the recent and current hunter-gatherer literature and drawing on our current work from western New South Wales, Australia, and southwest Wyoming, USA. We argue that neither of the current interpretative approaches to the hunter-gatherer archaeological record, ethnoarchaeological models or insights derived from behavioral ecology, deal adequately with the temporality of the record. Integrating the temporality of data and interpretation suggests to us a third way, whereby we can use explanations developed by viewing the archaeological record at a variety of scales to create a rich historical tapestry of past human behavioral variability.

\section{TEMPORAL SCALE IN ARCHAEOLOGY}

Measuring time in a number of different ways frees the archaeologist to search for processes operating at different temporal scales (Fletcher, 1992). However, this liberty brings with it the responsibility of ensuring that the scale of explanation meshes with both the scale of observation and the temporal scale of archaeological deposits. Unfortunately, the "Tyranny of Familiar Things", to use Plog's (1974) phrase, means that it is easy to adopt a common sense approach and see archaeological materials as the products of daily living. From this point of view, the archaeologist simply assumes that both behavior and deposition occur at the same temporal scale as that experienced at the "ethnographic" (Binford, 1981) or "human scale" (Stein, 1993, 2001), i.e., at intervals consistent with the life of the observer (Wandsnider, 2003). In almost every instance, however, the processes operating to create archaeological assemblages reflect a scale that is likely to be many times longer than that of daily living, an observation made by Binford (1981) in his discussion of the Pompeii premise (see also Foley, 1981). This frequently creates a disjuncture between the scale of observation and the scale of interpretation.

Recognition of this disjuncture dates at least from the 1980s with a seminal paper by Bailey (1983). Since that time, case studies and theoretical statements have appeared under the title "time perspectivism" (e.g., Bailey, 1981, 1987; Fletcher, 1992; Murray, 1997, 1999, 2003; Stern, 1993, 1994, Stern, et al., 2002). Despite this attention, there remains in archaeology a void between the scales at which theoretical models are constructed and the scales of the units adopted to collect and aggregate data used in evaluating these models.

In the search for interpretative models, archaeologists frequently appear as itinerant foragers, willing to scour other disciplines for theoretical resources. The pickings seem so much richer in the ethnographic, historical, and ecological literature. Nowhere is this truer than in hunter-gatherer studies where, as we argue below, ethnography (either current or of the recent past), ecology (in the form of evolutionary ecology), and forms of evolutionary theory now underpin most hunter-gatherer 
studies conducted in North America and Australia. To the "Tyranny of Material Things" can be added versions of Alcock's (1993) "Tyranny of Historical Records", Wobst's (1978) “'Tyranny of the Ethnographic Record", and a yet to be articulated "Tyranny of Ecological Models". While all these sources - historical records, ethnographic records, ecological models - are rich in detail, thereby contrasting with the apparent poverty of the archaeological record, their richness emphasizes the short-term over the long-term, multitemporal historical record, the very attributes that make the archaeological record so fascinating to study!

In what follows, we argue that all three sets of models (i.e., involving lifeways ethnography, historical documents and ecology) are useful for interpreting huntergatherer behavior only if history is ignored and time is characterized as flat, an observation made by Bailey (1983:170) when referring to structural functional models. Change, when it occurs, is punctuated, involving the transition from one stable state to another. We therefore find this characterization of human history most unlikely and suspect that it flows from a lack of consideration of temporal scale.

\section{TEMPORAL SCALES AND HUNTER-GATHERER RESEARCH}

Archaeologists have conducted research on deposits created by hunter-gatherers at a variety of temporal scales reflecting the operation of the various tyrannies noted above. While archaeological hunter-gatherer research is richer than we can portray here, we recognize two distinct modes of analysis and interpretation using two different temporal scales.

\section{"Pompeii"' Deposits and Functional Interpretation}

The first mode of temporal scales relies on, or attempts to warrant, the assumption that the deposits under study may be interpreted according to the "human scale" (Stein, 1993), as though they represent "Pompeii" deposits, i.e., fine grain or fine resolution deposits preserving "frozen-moments"' or short duration events in time. Most archaeologists working in Australia and North America recognize that some, probably most, deposits represent a form of palimpsest, but this assessment rarely affects their interpretations.

Because many researchers in Australia rely on ethnographic analogy as a source of models for interpreting archaeological materials, the formational history of the record they are interpreting becomes polarized. They consider sites as either in situ or mixed, the behavioral equivalent of single ethnographically conceived campsites or a jumble of material from multiple occupations. In effect, by using ethnography in these situations, they need not distinguish between the phenomenological, interpretative, and analytical scales Dobres discusses - beyond the mixed versus intact dichotomy - since interpretation can only exist at one (ethnographic) temporal scale. 
In North America, researchers have largely abandoned ethnographic analogy per se, instead substituting settlement components of Binford's (1980) model that relates structure of resources, hunter-gatherer mobility and settlement. However, as discussed below, the use of Binford's insights as direct analogs for the past has led North American archaeologists to the same interpretative dilemmas that their antipodean colleagues have reached.

In Australia, an unequal distribution of resources related to seasonal fluctuations in the environment has long formed the mechanism for explaining why people in the past performed different economic functions at the same places within a landscape (e.g., Thomson, 1939; Allen, 1972). In the arid zone, archaeologists generally assume that the most critical resource is water. Ethnographic case studies (e.g., Cane, 1984; Gould, 1969) suggest that during times of rain, populations disperse to exploit resources in regions where water sources are ephemeral. As the rains depart and the country enters into drought conditions, people retreat to more permanent water sources and exploit the resources around these locations. Archaeologists have used these observations as the basis for explanations of the distribution of archaeological sites (e.g., Allen, 1972; White and Peterson, 1969; Ross, 1984; Ross, et al., 1992; Smith, 1989, 1993, 1996; Veth, 1993; Williams, 1987). According to the model, those sites located away from sources of permanent water should show relatively few artifacts with little evidence for maintenance activities, while those closer to more permanent water should have more abundant artifacts and show a greater range of materials and artifacts, reflecting occupation by larger groups for longer periods (e.g., Veth, 1993:71).

Thus, in arid Australia, changes in water availability become the means by which archaeologists can assess intersite assemblage variability. They use different artifact assemblages to infer different activities practiced at particular locations, hence permitting the identification of site types (i.e., where type refers to function, Veth, 1993:80). Then they link these site types together in an ethnographically familiar, synthetic settlement system. The task of the archaeologist becomes one of measuring the temporal duration over which this system existed, together with its spatial extent. When they find similar sets of artifacts existing over extended periods, they can assume that the settlement/subsistence system has remained unchanged since occupation of the region began.

On a worldwide scale, the late occurrence of broad-spectrum changes in the Australian hunter-gatherer economies is well known. Changes elsewhere labeled as the broad-spectrum revolution occur from the mid to late Holocene in Australia, apparently unconnected with significant environmental change (Edwards and O'Connell, 1995). In the arid zone, the exploitation of grass seeds becomes important (Smith, 1986) and population increases, although there is debate about whether increasing numbers of people were the trigger for (e.g., Smith, 1989), or a consequence of (e.g., Veth, 1989), the late Holocene changes. Either way, the assumption is that people adapted to the Australian arid zone by implementing a series of technological and social solutions and, consequently, producing a characteristic settlement pattern.

Our concern with the application of such models to Australia centers on the utility of ethnographic models in the interpretation of long-term historically derived 
archaeological records. The problem is that functionalist interpretations of artifacts have changed over recent years. Ethnoarchaeological studies have shown, for example, that discard behavior is much more important than function in determining the spatial association of artifacts (Wandsnider, 1996). Ethnohistoric, ethnoarchaeological and experimental studies also report little relationship between artifact form and function (e.g., Hayden, 1979). In Australia, as elsewhere, similar artifact forms appear to have had a range of functions in the past while, conversely, a range of different artifact morphologies had single functions (e.g., Kamminga, 1982).

The implications of these studies for the identifications of site types seem clear: if assemblages do not represent tool kits, if the spatial association of artifacts reflects discard behavior rather than the existence of activity areas, the inference of a single or limited range of functions for a site must be viewed with skepticism. Following on from this, the inability to determine site function must call into question the nature of the Australian settlement pattern reconstructions, particularly the substantive transferal of ethnographically derived, short-term (i.e., seasonal) mobility models to explain long-term accumulations of artifacts.

In contrast, several factors have contributed to the demise in North America of an explicit ethnographic reconstructive orientation. First, starting especially in the late 1970s, a number of researchers critiqued the practice of reconstructing the past using ethnographic units. Wobst (1978) called attention to the abnormal sample that ethnography provides and to the ethnographic practice of normalizing important variation. Dunnell (1980) heavily criticized some of the early New Archaeologists for their reliance upon ethnographic concepts and units. In his analysis of the behavioral archaeology program, Binford (1981) argued, echoing Clarke (1973), that archaeological deposits refer to another order of reality, something attributable to an interpretative unit, a cultural system operating over the medium- and long term, as opposed to an empirical unit, such as an ethnographic group.

Second, the experience of North American archaeologists with the archaeological record made it very clear that simple application of ethnographic models those dealing with the articulation of functional settlement units - to archaeological deposits was flawed (Ramenofsky and Steffen, 1998:9). Instead, they began to talk of land use, by which they attempted to explain archaeological patterning in the long term. Thomas' $(1973,1975)$ and Bettinger's (1977) attempts to generate expectations for the archaeological record if Great Basin locations were utilized in the distant past, as documented by Steward for the Shoshone recent past, are only two such examples (see also Dancey, 1973; Jones, 1984).

Third was the publication of Binford's (1980) "Willow Smoke and Dog's Tails". Binford described and explained patterned variation in hunter-gatherer mobility and settlement according to the spatial and temporal structure of critical resources. He offered a conceptual schema to help understand some of the principle sources of variation seen in hunter-gatherer mobility and settlement. $\mathrm{He}$ distinguished between foragers, employing residential mobility to move consumers between patches of low abundance resources, and collectors, whose mobility is tethered to stores and who employ logistical mobility to provision consumers from widely dispersed, seasonally superabundant patches. To aid his discussion, 
From all of these sources followed a reconfiguration of the ethnographic analogical arguments so widely seen in Australian applications. For example, archaeologists discussed the degree to which their evidence indicated forager or collector adaptations (e.g., Sanger, 1996) or the degree to which one could use their evidence to stipulate these adaptations (e.g., Cowan, 1999). In other applications, archaeologists relied on the site types (residential camps, field camps, stations, caches, and locations) that Binford had identified as created through different deployments of residential and logistical mobility (see Simms, 1992 for an elaboration of this contention). Such applications confused the substantive content of Binford's forager-collector contribution with its conceptual content. For this reason, they committed exactly the same sins already detailed above for the Australian case.

\section{Palimpsest Deposits and "Strategic" Interpretations}

As Dunnell (1980) notes, one of the major research foci of the New Archaeology was the nature of the archaeological record, how it formed, and how we could interpret it. In the early 1980s, the "Pompeii premise" debate between Binford (1981) and Schiffer (1985) addressed the interpretative implications of the timeaveraged nature of archaeological deposits. In contrast to "Pompeii" assemblages, Binford discussed "palimpsest deposits," that is, coarse-grain or -resolution deposits representing the accumulation of materials over decades if not hundreds of years. He and Foley (1981) argued that with such assemblages, the ethnographic time of daily living was masked by stronger patterns introduced by the longer-term operation of human settlement and mobility patterns. Furthermore, both authors contended that processes unfolding in archaeological rather than ethnographic time were the rightful objects of archaeological study.

Beginning in the 1990s, North American archaeological literature on huntergatherers reflected the dual impact of the thinking articulated by Binford (1981) and Foley (1981) as well as the influence of optimal foraging theory and behavioral ecological research (e.g., Torrence, 1989; Bettinger, 1991). Archaeologists described past hunter-gatherer behavior using the concept of "strategies" similar in form to the analytical evolutionary stable strategies (ESS) of evolutionary ecology. They undertook studies that recognized mobility strategies (e.g., Amick, 1996; Bamforth and Becker, 2000; Smith and McNees, 1999), technological and land use strategies (e.g., Cowan, 1999), reproductive strategies (e.g., Bettinger, 1993), and subsistence strategies (e.g., Dering, 1999; Stafford, et al., 2000).

Australian archaeologists were obviously aware of these theoretical developments in North America. In recent years, numbers of studies have sought to define strategies following Binford and other North American authors rather than constructing functional settlement patterns. Hiscock, for instance, has considered both technology (e.g., Hiscock, 1996) and assemblage composition (e.g., Hiscock, 1994) from the viewpoint of behavioral ecology in an attempt to explain changes in mid to late Holocene stone artifact assemblages in Australia. In the former study, he cites changing strategies as the reason for differences in the degree of bipolar flaking present in sites in the north of Australia. In the later study, he explains the presence 
of a range of new artifact forms (adze bits, backed blades and seed grinding gear) as adaptations to the risks involved in moving into new, particularly arid, environments in the mid-Holocene. McNiven (1994) has also used North American studies in his attempt to relate increases in the frequency of certain tool types and the presence of exotic raw materials to the changes in mobility strategy evidenced by Late Pleistocene sites in southwest Tasmania (but see Holdaway, 2000, 2004).

Both the Australian and North American studies use strategies as "problemsolving processes that are responsive to conditions created by the interplay between humans and their social and natural environment" (Nelson, 1991:58). The "problem" to be solved, sometimes unstated, is usually related to minimizing risk, optimizing stone tool resources, maximizing reproductive success and so on - in other words, the grist of optimal foraging and behavioral ecology.

The second important research emphasis, launched by the New Archaeology in the 1970s but largely unexploited until much later, is middle range research. This endeavor links archaeological material with the interpretation of cultural dynamics and makes possible the strategic interpretations discussed above. For example, Amick (1996) and Bamforth and Becker (2000) rely on the reductive nature of chipped stone technology and various reasonable stipulations derived thereof to offer expectations for archaeological assemblages formed because of different configurations of Paleoindian mobility. Dering (1999) and Stafford et al. (2000) rely on plant community ecology (productivity, diversity, abundance, rebound rates) to situate their interpretations of Archaic age subsistence strategies in west Texas and southern Illinois, respectively. In Australia, Cosgrove and Allen (2001) use the behavior of Bennetts Wallaby together with paleoenvironment reconstruction and faunal analysis to understand prey choice and processing patterns. Important in all these applications are two things: the emphasis on variation and its explanation as the differential implementation of strategies; and the consequences such strategies, as defined, have for the differential deposition of artifacts with different use-lives and temporalities. ${ }^{1}$

How compatible are "strategic" interpretive units with the palimpsest nature of archaeological deposits resulting from hunter-gatherers? At face value, they appear very compatible. These "strategies" only become recognizable because of repeated behaviors resulting in the patterned deposition of artifacts. Indeed, for the archaeological record to register these strategies, these behaviors must have been consistent over decades if not centuries.

However, such patterning also suggests great stability in aspects (i.e., the common mundane, or the rare, or both) of land use organization, at least for periods extending to decades and more. Given our current understanding of hunter-gatherer land use and organization, can we expect this kind of intra- or inter-generational stability or is it the product of the application of concepts ill-suited to modeling

${ }^{1}$ It is important to note that some archaeologists simultaneously pursue both approaches. Cowan (1999) attempts to recognize different subsistence and land use strategies in terms of different lithic technological strategies for Archaic and Woodland western New York, He relies on sophisticated analyses of chipped stone assemblages and explicitly considers the possibility that the patterning he documents may relate to the convolution of multiple disparate strategies. For unknown reasons, however, something compels him to translate his interpretations of past subsistence and land use into the settlement system lexicon described above for Australian hunter-gatherers, rather than offering it in terms of "strategies." 
change? The problem shows clearly in Australia, truly the continent of huntergatherers. Since it had neither agriculture nor complex society, Australia always lacked clear indicators of major changes in either settlement patterns or adaptive strategies. As discussed above, the Holocene apparently had only one major change, sometime around 5,000 BP, which produced various phenomena that some archaeologists have linked together with a theory of intensification (the Australian equivalent of the broad spectrum revolution [Lourandos, 1997]). They explain this change in a variety of ways, some of the more popular in recent years based on social rather than demographic change. Yet, regardless of the theoretical background they adopt, their explanations as a whole have the same all or nothing quality. When they detect change, they characterize it as instantaneous and total. The shift seems mechanical - as if history did not exist in the movement from one stable system to another. To us this seems an unlikely situation either in the prehistory of Australia or elsewhere. "Strategies" are strategies in metaphor only. They are abstractions from innumerable individual strategic (the word as commonly used) acts pursued by members of one or more constantly changing ethnic groups. Rather than modeling continuity, we should be using the archaeological record to resolve historical change, since archaeology alone is able to address this question.

\section{TEMPORAL STRUCTURE AND PLACE HISTORY INTERPRETATIONS}

Archaeological sites in the arid zones of Australia and North America, like archaeological sites anywhere, are places where artifacts and sediments accumulate. In both these regions, surface exposures of artifacts are either lag deposits or simple accumulations. In the arid zone of western New South Wales, Australia, artifact accumulations were buried until relatively recently. Their modern day exposure can be securely associated with 19th century grazing activity when European pastoralists introduced cloven hoof domestic livestock to an environment that had until then been the domain of marsupials (Fanning 1999, 2002). The resulting vegetation loss and topsoil erosion is hard to comprehend. Literally millions of stone artifacts today lay exposed over thousands upon thousands of hectares. Although exposure has sometimes resulted in hopelessly mixed hydraulic jumbles, more often it has been gentler, resulting in the loss of vertical integrity but largely retaining horizontal position (Fanning and Holdaway, 2001a). In effect, then, erosion has excavated large regions, producing the types of exposures that archaeologists excavating traditionally would take a generation to achieve (Holdaway et al., 2000).

In the Wyoming Basin of intermountain North America, there are both deeply buried deposits and surface deposits. Not surprisingly, the topographic landform and vegetative cover contemporary with occupations in antiquity contributes to their present day form, with sites exposed on terraces, buried in swales and along slopes, and exposed or buried in dune fields (see, Eckerle, 1997; Ebert, 1992 for discussion). In the Wyoming Basin proper, it appears that surface deposits represent only a small portion of the subsurface assemblage. For example, dense artifact 
accumulations in the Seedskadee project area are one-to-two orders of magnitude less than excavated deposits from the same area. Yet, the same kinds of artifacts appear in both surface and subsurface assemblages, suggesting that surface assemblages are a representative sample of the near surface buried assemblages. Features, of course, are much better preserved and documented in excavated contexts.

Studying both extensive lag (interior Australia) and accumulated (Wyoming Basin) deposits forces us to recognize that our archaeological sites are timetransgressive in nature, with different temporal structures (sensu Murray, 2003), i.e., grain (or resolution), extent (or scope) and depositional gaps. That is, they encourage a third mode of analysis and interpretation beyond the functional interpretation of "Pompeii" deposits and the simple strategic interpretation of palimpsest deposits. These assemblages have not accumulated as the result of a single "occupation" - or more correctly, given the lagging or accumulation processes, there is no visible stratification to support the interpretation of assemblages as "living floors". Instead, these assemblages reflect repeated use of a place, with contributions from all the artifact-producing activities that have occurred there. Thus, it may be more profitable, and perhaps more accurate, to visualize the site as a record of deposition as opposed to one of function. Since vertical integrity was either never present or has been lost, there is no reason to think of spatial association as analogous to functional association. Similarly, since the artifacts represent the discard from many events, it is easy to imagine assemblages accumulating as the result of several different behavioral strategies.

In developing ways to interpret records such as this, archaeologists often adopted Binford's (1980) concept of foragers and collectors and his discussion of site types. Because the archaeological record is time-averaged, however, assemblage site types do not relate specifically to either foragers or collectors. Here, Binford's discussion of the Mask site (Binford, 1978) becomes important. As described, the Mask site consists of artifacts relating to a number of activities at a location that "functioned" as a hunting lookout. However, the "function" of the artifact sets has little apparent relationship to the "function" for which the site was occupied. Instead, Binford stresses the complex relationship between identifications of site function and the activities that lead to the incorporation of artifacts into the archaeological record. The way archaeologists determine site function, as with the categorization of artifacts, depends on which of the activities evident at the site they give precedence. Archaeological sites do not form a record of the activities that occurred at a location, but are formed instead by the act of artifact discard at a location.

The palimpsest nature of time-averaged archaeological deposits compels us to reject their categorization as single functional entities. Binford's discussion of foragers and collectors (1980) is of little use if one understands it as a means of obtaining prehistoric settlement patterns through the identification of site types. Nor is it useful to think of assemblages as resulting from the operation of a single strategy. Time-averaged deposits do not link together as though the operation of a single set of integrated activities produced them (Stern, 1994). Instead; we see in Binford's writings how to understand the nature of artifact deposition as the product of a number of settlement patterns or as the outcome of a variety of resource 


\section{Temporal Scales and Archaeological Lands}

gathering strategies. As Binford (1982) showed, depending on where a site fits into a particular strategy, discard rates for different types of artifacts will vary. However, a single location may change its place and role in a strategy through time. One settlement system may overlay another as resource availability changes. Therefore, artifacts from one location are not the products of either a single synchronic settlement system or a single strategic system. Rather, they represent the cumulation of discard events over the entire history of uses of that place. We emphasize this crucial point in our work because there is no possibility of stratigraphically distinguishing different "occupations." The material products of all activities that occurred at one place in the landscape create a palimpsest. Therefore, we do not attempt to isolate individual occupations or depositional events because we see the relative complexity of the assemblage composition as an indicator of the complex history of place use. Of course, resource availability may not diminish at some locations, leading people in the past to use such places in much the same way over significant periods. However, given the vast time spans often represented in archaeological deposits, we suspect this to be the exception rather than the rule. At any rate, rather than assuming redundancy, and therefore continually seeking to synthesize a single strategy or settlement system to exclude all variability, we prefer to make investigating assemblage variability the goal of our research.

\section{Environmental Variability}

The environments with which we deal are highly variable and interpretable at a variety of temporal scales. In Australia, for instance, the stratigraphic sequence between the late Pleistocene and the late Holocene one of us has investigated has long periods of erosion separated by much shorter periods of deposition or surface stability (Fanning and Holdaway, 2001b). Archaeological materials therefore appear only on these depositional or stable surfaces. One period of surface stability occurred during the last 2,000 years before European settlement. We have dated many heat retainer hearths to this time. Despite the geological stability, however, the hearth dates tell of a fluctuating human presence. During one period of around two hundred to three hundred years, which may correlate with an increase in temperature known worldwide as the Medieval Climatic Anomaly, occupation appears to have ceased. Both before and after this gap in occupation, hearths were constructed but analysis of the radiocarbon results shows that hearth construction was occasional, occurring every few decades (Holdaway et al., 2002). Based on the location of the dated hearths, there is little evidence that the occupants at any one time were aware of those who had occupied the valley previously. Hearths with different age estimates, for instance, are side by side with no evidence of reuse. Therefore, hearth construction is discontinuous over two millennia, continuous at the scale of centuries within single millennia, and discontinuous again at the scale of decades. The history of place use at this location is one of desert-swapping and variability - change that is visible only if sufficient time passes for a patterned archaeological record to accumulate and if the archaeologist explores this variability at multiple scales. 
Similarly, in the Wyoming Basin, Smith and McNees (1999) document clear evidence for persistent places (Schlanger, 1992), i.e., places with Archaic-age slablined pits visited repeatedly over a period of hundreds of years as demonstrated through chronometric dating. During the same period, at other locations in the basin, contributors to Larson and Francis (1997) point to the presence of pit houses, suggesting dedicated and deliberate time-transgressive use at these locations. At still other locations in the basin, especially in contemporary-dune fields with recent assemblages, both surface and subsurface archaeological records document place use with no evidence of anticipated return. Spatial contiguity in stratified artifact distributions (Dewar and McBride, 1992) indicates subsequent returns (as at the multiple multicomponent sites documented through cultural resource compliance activities in the basin, e.g., Taliaferro, Smith and Creasman, 1988). There is little evidence, however, that those who returned to particular locations were aware of previous occupations. The very high proportion of the chipped stone debris resulting from biface reduction, even though tool-quality cobbles are often (but not always) widely available, points to both planned greater mobility and planned short occupations (as per arguments offered by Kelly, 1988; see also Bamforth and Becker, 2000). At this point, the data seem to point to the practice of deserthopping by Archaic and Late Prehistoric populations, with repeated movement throughout and, according to Smith's (1999) analysis of obsidian source-distance relationships, just outside the basin proper.

\section{Assemblage Variability}

Thus, those who assume that they can apply single settlement systems or single strategies to interpret the archaeological records of foragers and collectors are failing to consider environmental variability. Variability in strategies, rather than continuity, provides the key to unlocking the history of place use. Take a curated artifact. Its place of use may vary during its use life as it is transported from location to location (Kuhn, 1994; Shott, 1996). Eventually the tool will wear out and be deposited in a site. Clearly, in such a case, one cannot treat locations of use and location of deposition as though they were one in the same. There is an argument that a closer relationship between function and location of deposition exists for tools with short use lives. However, this ignores both the general lack of specificity of tool function and form and the specific results of Binford's Mask site research, as discussed above. There may be many different kinds of short-term activities represented at a site and yet these activities may have little relation to site function.

These problems reduce the utility of function as an organizing concept with which to understand the distribution of artifactual material across a landscape. The alternative is to see assemblage composition not in synchronic functional terms, but as the result of a series of discard events distributed through time (Shott, 2003). Certainly, artifacts served purposes but the users may or may not have carried out these purposes at the places they abandoned them (Binford, 1979). Archaeologists have spent a great deal of time showing that there is little casual association 
between the functions an artifact performed and the location of its discard. Instead of concentrating on the function of artifacts, we suggest that it is more profitable to concentrate on their discard. Barring post depositional changes, we can be sure that the places we find artifacts are the places where they were abandoned. Thus, the association between location and discard is much more secure than the association between location and use.

What we need is an understanding of the significance of the association between location and discard. Here we suggest a return to the notion of time provided in the example of the deposition of a curated artifact discussed above. People make some artifacts for use over time, and they carry and use them in a variety of different locations. They discard such artifacts when they are no longer capable of fulfilling a particular set of functions - when they are worn out. The place where discard occurs depends on where the user is at the time the artifact wears out. Seen from this perspective, discard has a temporal quality. In the simplest formulation of this model - an idealized scenario that does not account for the life history of all curated artifacts - discard will occur most often where the people using curated artifacts spend the most time. If they use these artifacts for the same length of time at each place, the expended artifacts will accumulate uniformly across space. If, however, they use them in proportion to the amount of time they spend at one location, they will discard more expended curated artifacts over time at these locations.

In addition, the notion of temporality need not rest solely with curated artifacts (Holdaway, et al., 2000, 2004; Shiner, et al., 2005). Economic decisions based on optimality models may also relate to time rather than function. In stone artifact analysis, for instance, one may interpret choice in such variables as raw material and degree of core reduction in similar ways. Since cores of different materials tended to travel from location to location before discard, one may infer occupation duration from the degree to which reduction debris at a site is local or imported. During fleeting occupations, people would tend to transport materials to a site rather than seek out and use local materials (Elston, 1990). Limited use of this material would result in minimal discard, perhaps the occasional abandonment of an expended tool or the discard of resharpening flakes. In contrast, during prolonged occupations, they would make much greater use of local material. With less need to conserve imported tools and raw materials, they would tend to use them up, creating more reduction debris - if for no other reason than continued occupation at one location limited the chance to visit more distant sources (Elston, 1990).

\section{Accumulation as History}

From a temporal perspective, an artifact assemblage at a site preserves a history of the use of that site. Since desertic hunter-gatherers were most often mobile, it is most unlikely that locations had continuous use. As Binford demonstrated, huntergatherer strategies, or forager and collector modes, reflect the nature of the environment, particularly the degree to which people may have repeatedly used a place. 
It follows that a site's artifact assemblage records not the discard from single events but the accumulation from all events within one stratigraphic division.

The interpretation of assemblages from a temporal perspective permits an understanding of the sum of all activities at a particular locality in the past. From this perspective, we are not interested in isolating single events from the mix that occurred through time. Nor are we interested in averaging the events or determining which event was most common. The pattern comes from the outflow from all discard events. It is the complexity, or otherwise, of the assemblage at a particular location that is of interest as an expression of the history of the use of place.

Certainly, archaeologists will still be able to tell something about the range of activities performed at a particular location in the past and this knowledge will be of considerable interest. However, of more significance will be the sum of the activities that accumulated at this place through time. As discussed above, synchronic functional assessments of settlement pattern fail because they cannot deal with a dynamic past that was in a constant state of flux. Studies that emphasize strategies do not fare any better. Archaeology needs to outgrow a functionalist, ahistoric anthropology. The search for living floors and the "cautionary tale" of ethnoarchaeological studies demonstrate a concern for identifying the material manifestation of events as the sole basis for inference about the past. However, such studies ignore human variability. Why should we expect the archaeological record representing events distributed across hundreds or even thousands of years to mimic short duration events? Gamble (1999:68) identifies "flagship" (read "those with the best information content") sites as those with pristine artifacts, presumably, where accumulation time is short and deposition rapid. We disagree. Pattern in the archaeological record comes from the accumulation owed to multiple events. In other words, the power of assemblage analysis comes from the analysis of assemblage variation, and multiple events create this variation. We will learn relatively little by studying the archaeological manifestation of single events. Living floors, even if we could regularly identify them, will tell us little about the past because they sample time at only one point. Pattern is much more significant if it is the result of the accumulation of artifacts due to time-transgressive behavior.

\section{DISCUSSION}

The temporal structure of deposits and the temporality we can infer from the artifactual record permits the assessment of multiple patterns understandable at a variety of temporal scales. Understanding human environment interaction therefore becomes a matter of relating the tempo and mode of artifact accumulation with the tempo and mode of physical and social environmental change (Fletcher, 1992). Three observations follow.

First, we see this time perspectivism approach as a new way of dealing with landscape and the interpretation of the strategies critiqued above. It is not that we need to individually resolve the multiple strategies that have produced assemblages. Rather the analysis of assemblage variation provides the means to determine place use histories, and, from there we can approach the interpretation of various strat- 
egies pursued in the past. We have therefore shifted the search for strategies from analyses aimed at defining synchronic moments in the past to patterns of variation generated through time. Previous approaches to either settlement pattern research or to the isolation of strategies often required limited artifact analysis. In many settlement pattern studies, artifact assemblages are little more than Stone Age visiting cards (Isaac, 1981) - markers of the use of a location in the past but little else. In such studies, site type identification does not require much artifact analysis. Sometimes, the presence of a few artifact types will do.

Alternatively, in the search for strategies, some archaeologists have turned attention to single classes of artifact (in North America, point types are most common). We suspect that the Stone Age visiting cards left by prehistoric peoples have produced distributions of sites across many landscapes in different continents that appear largely similar. What these visiting cards hide, however, are assemblages that record a huge variety of depositional histories with complex patterns of human-environment interactions. In the search for strategies, the artifact analyses are more complex, since they involve considerations of optimality through such factors as design or raw material acquisition, but they are ultimately limited in their facility for revealing historical variation. Strategies are absolute. They can change completely or not at all. Modeling the archaeological record as the product of functioning systems seems to promote an unchanging past. In contrast, investigating the temporal nature of the archaeological record allows us to begin to model the complexities of human environmental interactions.

Second, one of the questions that remains unanswered is whether the patterns attributed to the operation of strategies are apparent at a variety of different temporal scales. If they are not, and we suspect that this is likely to be the case in many situations, it begs the question of how we should interpret the patterns we are able to identify. What "strategies" are observable only over the long-term, and how should we differentiate them from "strategies" observable at shorter temporal scales? From studies of historical change may come a clearer understanding of the behavioral regularities from which "strategies" are abstracted. Questions concerning the temporal scale at which any patterns emerge rarely appear in either the Australian or North American literature, yet they remain of fundamental import if one is to meet concerns about the lack of match between the scales of interpretation and observation.

Third, understood from a temporal perspective, the challenge becomes how to assemble multiple, individual place use histories so as to understand the patterned use of space over the long term not by groups of individuals belonging to particular ethnic groups, nor by groups reducible to single structural poses or strategies. The material record of past behavior produces its own form of history. We can seek explanation for this history by analyzing the material remains at a variety of temporal scales. The patterns we see are the product of human behavior but not isolatable into units familiar to students of short-term ethnography or at least ethnography as it is currently written (Murray, 1997). Historical continuities exist in material culture but these continuities do not necessarily correlate with what people think either about the material culture or about themselves. As one of us has been able to show (Wandsnider, 1998), two different ethnic groups, each leaving behind markedly different material records reflecting markedly 
different settlement patterns and distinct behavioral strategies, can use a single place. Place use is the constant here. The history of use of place is no more or less valid because two different ethnic groups used a single location. Group ethnicity provides one way of dividing the material record into classes for analysis, and the nature of their economic pursuits forms another, but these are not the only possible analytical units nor are they oftentimes obtainable. As historical archaeologists have been able to show (e.g., Lightfoot, 1995; Lightfoot, et al., 1998), the ethnic identity of the people who used and abandoned artifacts is much less interesting than the fact that the artifacts were used and abandoned at a particular place and time.

\section{CONCLUSION}

Thirty years ago, Plog $(1973,1974)$ urged archaeologists to move beyond synchronic interpretations of a diachronic archaeological record. Research on the nature of the archaeological record during the 1970s and 1980s highlighted its temporal structure and the multiple temporal scales at which one might productively approach it, adding another dimension to Plog's critique. Archaeologists have begun to move beyond functional interpretation of hunter-gatherer deposits to interpretations of stable strategies. The next step, we suggest, is to consider formationally informed accumulation and place histories, sensitive to temporal structure, as the lens through which a variety of strategies, operating at a variety of tempos, become evident.

ACKNOWLEDGEMENTS A version of this paper was given at an SAA symposium in 2001 organized by Amber Johnson and Lewis Binford. Harry Allen, Peter Bleed, Angela Close, Mathew Dooley, Don Grayson, Thegn Ladefoged, and Julie Stein provided comments on earlier drafts. The paper was completed while one of us (SH) was a visiting scholar at the Department of Anthropology, University of Washington.

\section{REFERENCES}

Allen, H., 1972, Where the Crow Flies Backwards. PhD dissertation, University of Sydney, Sydney.

Amick, D.C., 1996, Regional Patterns of Folsom Mobility and Land Use in the American Southwest. World Archaeology 27:411-426.

Alcock, S.E., 1993, Graecia Capta: The Landscapes of Roman Greece. Cambridge University Press, Cambridge.

Bailey, G., 1981, Concepts, Timescales and Explanations in Economic Prehistory. In Economic Archaeology: Towards an Integration of Ecological and Social Approaches, edited by A. Sheridan and G. Bailey, pp. 97-117. BAR 96, Oxford.

Bailey, G.N., 1983, Concepts of Time in Quaternary Prehistory. Annual Review of Anthropology 12:165-192.

Bailey, G.N., 1987, Breaking the Time Barrier. Archaeological Review from Cambridge 6:5-20.

Bamforth, D.B., and Becker, M.S., 2000, Core/Biface Ratios, Mobility, Refitting, and Arifact Use-Lives: 
Behrensmeyer, A., Kidwell, S., and Gastaldo, R., 2000, Taphonomy and Paleobiology. Paleobiology 26:103-147.

Bettinger, R., 1977, Aboriginal Human Ecology in Owens Valley: Prehistoric Change in the Great Basin. American Antiquity 42:3-17.

Bettinger, R., 1991, Hunter-Gatherers Archaeological and Evolutionary Theory. Plenum Press, New York.

Bettinger, R., 1993, Doing Great Basin Archaeology Recently: Coping with Variability. Journal of Archaeological Research 1:43-66.

Binford, L., 1978, Dimensional Analysis of Behavior and Site Structure: Learning from an Eskimo Hunting Stand. American Antiquity 43:330-361.

Binford, L., 1979, Organization and Formation Processes: Looking at Curated Technologies. Journal of Anthropological Research 35:255-273.

Binford, L., 1980, Willow Smoke and Dogs' Tails: Hunter-Gatherer Settlement Systems and Archaeological Site Formation. American Antiquity 45:4-20.

Binford, L., 1981, Behavioral Archaeology and the "Pompeii Premise". Journal of Anthropological Research 37:195-208.

Binford, L.R., 1982, The Archaeology of Place. Journal of Anthropological Archaeology 1:5-31.

Cane, S., 1984, Desert Camps: A Case Study of Stone Artefacts and Aboriginal Behaviour in the Western Desert. PhD dissertation, Department of Prehistory, Research School of Pacific Studies, Australian National University, Canberra.

Clarke, D.L., 1973, Archaeology and the Loss of Innocence. Antiquity 46:6-18.

Cosgrove, R., and Allen, J., 2001, Prey Choice and Hunting Strategy in the Late Pleistocene: Evidence from Southwest Tasmania. In Histories of Old Ages Essays in Honour of Rhys Jones, edited by A. Anderson, I. Lilley and S. O'Connor, pp. 397-429. Pandanus Books, Canberra.

Cowan, F.L., 1999, Making Sense of Flake Scatters: Lithic Technological Strategies and Mobility. American Antiquity 64:593-607.

Crumley, C.L., 1979, Three Locational Models: An Epistomological Assessment for Anthropology and Archaeology. Advances in Archaeological Method and Theory 2:143-173.

Crumley, C.L., and Marquardt, W.H., editors, 1987, Regional Dynamics: Burgundian Landscapes in Historical Perspective. Academic Press, San Diego.

Dancey, W.S., 1973, Prehistoric Land Use and Settlement Patterns in the Priest Rapids Area, Washington. $\mathrm{PhD}$ dissertation, University of Washington, Seattle.

Dering, P., 1999, Earth-Oven Plant Processing in Archaic Period Economies: An Example from a SemiArid Savannah in South-Central North America. American Antiquity 64:659-674.

Dewar, R.E., and McBride, K.A., 1992, Remnant Settlement Patterns. In Space, Time, and Archaeological Landscapes, edited by J. Rossignol and L. Wandsnider, pp. 227-256. Plenum, New York.

Dobres, M-A., 2000, Technology and Social Agency: Outlining a Practice Framework for Archaeology. B. Blackwell, Oxford.

Dunnell, R.C., 1980, Evolutionary Theory and Archaeology. Advances in Archaeological Method and Theory 3:38-99.

Ebert, J.I., 1992, Distributional Archaeology. University of New Mexico Press, Albuquerque.

Eckerle, W.P., 1997, Eolian Geoarchaeology of the Wyoming Basin: Changing Environments and Archaic Subsistence Strategies in the Holocene. In Changing Perspectives of the Archaic on the Northwest Plains and Rocky Mountains, edited by M.L. Larson, and J.E. Francis, pp. 139-167. University of South Dakota Press, Vermillion.

Edwards, D., and O'Connell, J., 1995, Broad Spectrum Diets in Arid Australia. Antiquity 69:769-783.

Elston, R.G., 1990, A Cost-Benefit Model of Lithic Assemblage Variability. In The Archaeology of James Creek Shelter, edited by R.G. Elston and E.E. Budy, pp. 153-164. University of Utah Anthropological Papers 115, Salt Lake City.

Fanning, P., 1999, Recent Landscape History in Arid Western New South Wales, Australia: A Model for Regional Change. Geomorphology 29:191-209.

Fanning, P., 2002, Beyond The Divide: A New Geoarchaeology Of Aboriginal Stone Artefact Scatters In Western NSW, Australia. PhD dissertation, Graduate School of the Environment, Division of 
Fanning, P., and Holdaway, S., 2001a, Temporal Limits to the Archaeological Record in Arid Western NSW, Australia: Lessons from OSL and Radiocarbon Dating of Hearths and Sediments. In Australasian Connections and New Directions: Proceedings of the 7th Australasian Archaeometry Conference, edited by M. Jones and P. Sheppard, pp. 85-104. Research in Anthropology and Linguistics 5, Department of Anthropology, University of Auckland, Auckland.

Fanning, P., and Holdaway, S., 2001b, Stone Artifact Scatters in Western NSW, Australia: Geomorphic Controls on Artifact Size. Geoarchaeology 16:667-686.

Fletcher, R., 1992, Time Perspectivism, Annales, and the Potential of Archaeology. In Archaeology, Annales, and Ethnohistory, edited by A.B. Knapp, pp. 35-50. Cambridge University Press, Cambridge.

Foley, R.A., 1981, A Model of Regional Archaeological Structure. Proceedings of the Prehistoric Society 47:1-17.

Gamble, C., 1999, The Palaeolithic Societies of Europe. Cambridge University Press, Cambridge.

Grayson, D.K., 1983, The Establishment of Human Antiquity. Academic Press, New York.

Gould, R., 1969, Yiwara: Foragers of the Australian Desert. Scribner, New York.

Hawking, S.W., 1998, A Brief History of Time. Bantam Press, London.

Hayden, B., 1979, Palaeolithic Reflections: Lithic Technology and Ethnographic Excavation Among Australian Aborigines. Australian Institute of Aboriginal Studies, Canberra.

Hiscock, P., 1994, Technological Responses to Risk in Holocene Australia. Journal of World Prehistory 8:267-292.

Hiscock, P., 1996, Mobility and Technology in the Kakadu Coastal Wetlands. Bulletin of the Indo-Pacific Prehistory Association 15:151-157.

Holdaway, S., 2000, Economic Approaches to Stone Artefact Raw Material Variation. In Australian Archaeologist: Collected Papers in Honour of Jim Allen, edited by A. Anderson and T. Murray, pp. 217-230. Coombs Academic Publishing, The Australian National University, Canberra.

Holdaway, S., 2004, Continuity and Change. An Investigation of the Flaked Stone Artefacts from the Pleistocene Deposits at Bone Cave South West Tasmania, Australia. Report of the Southern Forest Archaeological Project Volume 2, Archaeology Program, School of Historical and European Studies, La Trobe University, Melbourne.

Holdaway, S., Fanning, P., and Witter, D., 2000, Prehistoric Aboriginal Occupation of the Rangelands: Interpreting the Surface Archaeological Record of Far Western New South Wales, Australia. Rangelands 22:44-57.

Holdaway, S., Fanning, P., Witter, D., Jones, J., Nicholls, G., and Shiner, J., 2002, Variability in the Chronology of Late Holocene Occupation on the Arid Margin of Southeastern Australia. Journal of Archaeological Science 29:351-363.

Holdaway, S., Shiner, J., and Fanning, P., 2004, Hunter-Gatherers and the Archaeology of the Long Term: An Analysis of Surface, Stone Artefact Scatters from Sturt National Park, New South Wales, Australia. Asian Perspectives 43(1):34-72.

Isaac, G.L., 1981, Stone Age Visiting Cards: Approaches to the Study of Early Land Use Patterns. In Patterns of the Past Studies in Honour of Favid Clarke, edited by I. Hodder, G. Isaac and N. Hammond, pp. 131-155. Cambridge University Press, Cambridge.

Jones, G.T., 1984, Prehistoric Land Use in the Steens Mountain Area, Southeastern Oregon. PhD dissertation. University of Washington, Seattle.

Kamminga, J., 1982, Over the Edge: Functional Analysis of Australian Stone Tools. Occasional Papers in Anthropology, Number 12, Anthropology Museum, University of Queensland, St Lucia, Queensland.

Kelly, R.L., 1988, The Three Sides of a Biface. American Antiquity 53:717-734.

Kuhn, S.L., 1994, A Formal Approach to the Design and Assembly of Mobile Toolkits. American Antiquity 59:426-442.

Larson, M.L., and Francis, J.E., 1997, Changing Perspectives of the Archaic on the Northwest Plains and Rocky Mountains. University of South Dakota, Vermillion.

Lightfoot, K.G., 1995, Culture Contact Studies: Redefining the Relationship Between Prehistoric and Historical Archaeology. American Antiquity, 60:199-217.

Lightfoot, K.G., Martinez, A., and Schiff, A.M., 1998, Daily Practice and Material Culture in Pluralistic Social Settings: An Archaeological Study of Culture Change and Persistence from Fort Ross, 
Lourandos, H., 1997, Continent of Hunter-Gatherers: New Perspectives in Australian Prehistory. Cambridge University Press, Cambridge.

Marquardt, W.H., 1992, Dialectical Archaeology. Archaeological Method and Theory 4:101-140.

McNiven, I., 1994, Technological Organization and Settlement in Southwest Tasmania after the Glacial Maximum. Antiquity 68:75-82.

Murray, T., 1997, Dynamic Modelling and New Social Theory of the Mid- to Long-Term. In Time, . Process and Structured Transformation in Archaeology, edited by S.E. van der Leeuw and J. McGlade, pp. 449-463. Routledge, London.

Murray, T., 1999, A Return to the 'Pompeii Premise'. In Time and Archaeology, edited by T. Murray, pp. 8-27. Routledge, London.

Murray, T., 2004, Archbishop Ussher and Archaeological Time. In The Archaeologist as Detective: The Leo Klejn Festschrift, edited by L. Vishnyatsky, pp. 204-215. Folio Press, St. Petersburg.

Nelson, M.C., 1991, The Study of Technological Organization. Archaeological Method and Theory 3:57-100.

O'Neill, R.V., and King, A.W., 1998, Homage to St. Michael; or, Why Are There So Many Books on Scale? In Ecological Scale: Theory and Applications, edited by D.L. Peterson and V.T. Parker, pp. 3-16. Columbia University Press, New York.

Plog, F.T., 1973, Diachronic Anthropology. In Research and Theory in Current Anthropology, edited by C. Redman, pp. 181-198. John Wiley and Sons, New York.

Plog, F., 1974, The Study of Prehistoric Change. Academic Press, New York.

Ramenofsky, A.F., 1998, The Illusion of Time. In Unit Issues in Archaeology, edited by A.F. Ramenofsky and A. Steffen, pp. 74-84. University of Utah Press, Salt Lake City.

Ramenofsky, A.F. and A. Steffen, 1998, Units as Tools of Measurement. In Unit Issues in Archaeology, edited by A.F. Ramenofsky and A. Steffen, pp. 3-17. University of Utah Press, Salt Lake City.

Ross, A., 1984, If There Were Water: Prehistoric Settlement Patterns in the Victorian Mallee. PhD dissertation, School of Earth Sciences, Macquarie University, Sydney.

Ross, A., Donnelly, T., and Wasson, R., 1992, The Peopling of the Arid Zone: Human Environment Interactions. In The Naive Lands: Prehistory and Environmental Change in Australia and the Southwest Pacific, edited by J. Dodson, pp. 76-114. Longman Cheshire, Melbourne.

Sanger, D., 1996, Testing the Models: Hunter-Gatherer Use of Space in the Gulf of Maine, USA. World Archaeology 27:512-526.

Schiffer, M.B., 1985, Is There a "Pompeii Premise" in Archaeology? Journal of Anthropological Research 41:18-41.

Schindel, D.E., 1982, Resolution Analysis: A New Approach to the Gaps in the Fossil Record. Paleobiology 8:340-353.

Schlanger, S., 1992, Persistent Places. In Space, Time, and Archaeological Landscapes, edited by J. Rossignol and L. Wandsnider, pp. 91-112. Plenum, New York.

Shiner, J., Holdaway, S., Allen, H., and Fanning, P., 2005, Understanding Stone Artefact Assemblage Variability in Late Holocene Contexts in Western New South Wales, Australia: Burkes Cave, Stud Creek and Fowlers Gap. In Rocking The Boat: New Approaches To Stone Artefact Reduction, Use And Classification In Australia, edited by C. Clarkson and L. Lamb, pp. 67-80. British Archaeological Reports, International Monograph Series. Archaeopress, Oxford.

Shott, M., 1996, An Exegesis of the Curation Concept. Journal of Anthropological Research 52:259-280.

Shott, M., 2003, Size as a Factor in Middle Palaeolithic Assemblage Variation in the Old World: a North American Perspective. In Lithic Analysis at the Millennium, edited by N. Moloney and M. Shott, pp. 137-149. Archtype, London.

Simms, S., 1992, Ethnoarchaeology: Obnoxious Spectator, Trivial Pursuit, or the Keys to a Time Machine? In Quandries and Quests: Visions of Archaeology's Future, edited by L. Wandsnider, pp. 186-198. Volume 20. Center for Archaeological Investigation, Southern Illinois University, Carbondale.

Smith, C.S., 1999, Obsidian Use in Wyoming and the Concept of Curation. Plains Anthropologist 44:271-291.

Smith, C.S. and Creasman. S.D.. 1988, The Taliaferro Site: 5000 Years of Prehistory in Southwest Wyoming. Wyoming Cultural Resource Series No. 6. Bureau of Land Management, Cheyenne. 
Smith, C.S., and McNees, L.M., 1999, Facilities and Hunter-gatherer Long-term Land Use Patterns: An Example from Southwest Wyoming. American Antiquity 64:117-136.

Smith, M.A., 1986, The Antiquity of Seed Grinding in Arid Australia. Archaeology in Oceania 21:29-39. Smith, M.A., 1989, The Case for a Resident Human Population in the Central Australian Ranges During Full Glacial Aridity. Archaeology in Oceania 24:93-105.

Smith, M.A., 1993, Biogeography, Human Ecology and Prehistory in the Sandridge Deserts. Australian Archaeology 37:35-49.

Smith, M.A., 1996, Prehistory and Human Ecology in Central Australia: An Archaeological Perspective. In Exploring Central Australia: Society, the Environment and the 1894 Horn Expedition, edited by S.R. Morton and D.J. Mulvaney, pp. 61-73. Surrey Beatty and Sons, Chipping Norton.

Stafford, C.R., Richards, R.L., and Anslinger, C.M., 2000, The Bluegrass Fauna and Changes' in Middle Holocene Hunter-gatherer Foraging in the Southern Midwest. American Antiquity 65:317-336.

Stein, J.K., 1993, Scale in Archaeology, Geosciences, and Geoarchaeology. In Effects of Scale on Archaeological and Geoscientific Perspectives, edited by J.K. Stein and A.R. Linse, pp. 1-10. Geological Society of America, Boulder, Colorado.

Stein, J.K., 2001, Archaeological Sediments in Cultural Environments. In Sediments in Archaeological Context, edited by J.K. Stein and W.R. Farrand, pp. 1-28. University of Utah Press, Salt Lake City.

Stern, N., 1993, The Structure of the Lower Pleistocene Archaeological Record. Current Anthropology, 34:201-225.

Stern, N., 1994, The Implications of Time-Averaging for Reconstructing the Land-Use Patterns of Early Tool-Using Hominids. Journal of Human Evolution 27:89-105.

Stern, N., Porch, N., and McDougall, I., 2002, FxJj43: A Window into a 1.5-Million-Year-Old Palaeolandscape in the Okote Member of the Koobi Fora Formation, Northern Kenya. Geoarchaeology 17:349-392.

Torrence, R., 1989, Tools as Optimal Solutions. In Time, Energy and Stone Tools, edited by R. Torrence, pp. 1-6. Cambridge University Press, Cambridge.

Thomas, D.H., 1973, An Empirical Test for Steward's Model of Great Basin Settlement Patterns. American Antiquity 38:155-176.

Thomas, D.H., 1975, Nonsite Sampling in Archaeology: Up the Creek Without a Site? In Sampling in Archaeology, edited by J.W. Mueller, pp. 61-81. University of Arizona, Tucson.

Thomson, D.F., 1939, The Seasonal Factor in Human Culture Illustrated from the Life of a Contemporary Nomadic Group. Proceedings of the Prehistoric Society 5:209-221.

Veth, P., 1989, Islands in the Interior: A Model for the Colonisation of Australia's Arid Zone. Archaeology in Oceania 24:81-92.

Veth, P., 1993, Islands in the Interior: The Dynamics of Prehistoric Adaptations within the Arid Zone of Australia. International Monographs in Prehistory, Archaeological Series 3. Ann Arbor.

Wandsnider, L., 1996, Describing and Comparing Archaeological Spatial Structures. Journal of Archaeological Method and Theory 3:319-384.

Wandsnider, L., 1998, Landscape Element Configuration, Lifespace, and Occupation History: Ethnoarchaeological Observations and Archaeological Applications. In Surface Archaeology, edited by A.P. Sullivan III, pp. 21-39. University of New Mexico Press, Albuquerque.

Wandsnider, L., 2003, Solving the Puzzle of the Archaeological Labyrinth: Time Perspectivism in Mediterranean Surface Archaeology. In Side-by-Side, edited by S. Alcock and J. Cherry, pp. 49-62. Oxbow Press, Oxford.

White, C., and Peterson, N., 1969, Ethnographic Interpretations of the Prehistory of Western Arnhem Land. Southwestern Journal of Anthropology 25:45-67.

Williams, E., 1987, Complex Hunter-Gatherers: A View from Australia. Antiquity 61:310-321.

Wobst, H.M., 1978, The Archaeo-Ethnology of Hunter-gatherers or the Tyranny of the Ethnographic Record in Archaeology. American Antiquity 43:303-309. 